\title{
A literatura como meio de avaliação da produção científica e o problema da autoria em ciência ${ }^{1}$
}

\author{
Literature as a means of evaluation in Science and the \\ problem of scientific authorship
}

Profa $^{\mathrm{a}}$. Dra.

Cristina de Amorim Machado Universidade Estadual de Maringá cristina_machado@yahoo.com

Recebido em 10/07/16

Aceito em 04/11/16

Para citar este artigo: MACHADO, Cristina de Amorim. A literatura como meio de avaliação da produção científica e o problema da autoria em ciência. Em Construção. ano 1, n. 1, 2017, pp. 5-24. DOI:10.12957/ emconstrucao.2017.28122

\section{Resumo}

O objetivo deste artigo é examinar o problema da autoria em ciência, postulando que não só a imagem de ciência mudou nas últimas décadas, mas também o conceito de autoria. Ninguém negaria hoje, por exemplo, que a ciência é uma empreitada coletiva que circula e se modifica no processo, e que implica uma literatura científica cada vez mais colaborativa. No entanto, quando o número de atores da prática científica se multiplica e tantas vozes participam dessa cena para além dos cientistas, como definir a autoria em ciência? Como pensar em avaliação com base na literatura científica, considerando a emergência desse novo tipo de autor? Analisar o problema da autoria é importante por conta das demandas para reconhecer, responsabilizar e dar crédito em ciência, sobretudo em tempos de produtivismo baseado em bibliometria.

Palavras-chave; literatura científica, avaliação na ciência, autoria científica

\section{Abstract}

This paper intends to analyze the problem of scientific authorship. I suppose that not only the image of Science has changed in the last decades, but the concept of authorship as well. For example, nobody would deny that Science is a collective practice which circulates and is changed in the process. However, when the number of actors in the scientific practice multiplies and so many voices join the scene besides the scientists, how to define authorship in Science? How to think evaluation based on scientific literature, considering the emergence of this new kind of actor? Researching this problem is important because acknowledgment, accountability and credit are demanded in Science, specially in face of the big fast Science which is based in bibliometrics.

Keywords: scientific literature, evaluation in science, scientific authorship

1 O projeto de pesquisa que deu origem a este artigo contou com um auxílio financeiro do CNPq (Edital de Ciências Humanas, processo 408437/2013-8). Este trabalho não poderia ter sido feito sem as ricas discussões com os grupos de pesquisa Estudos Sociais e Conceituais de Ciência, Tecnologia e Sociedade e GP de Science Studies da UEM. Agradeço também às valiosas sugestões dos pareceristas da revista. 
A ciência não é um conteúdo, mas um modo de circulação.

Michel Serres, Diálogo...

Agradeça aos atores, não à autora - disse ele. - E a nós mesmos, que formamos a plateia.

Virginia Woolf, Entre os atos

\section{Introdução}

Em seu A arte de escrever, Arthur Schopenhauer (2013, p. 57) define três tipos de autores e os quantifica: 1) os que escrevem sem pensar, de memória ou com base em livros alheios (a maioria); 2) os que pensam enquanto escrevem, pensam para escrever (numerosos); e 3) os que pensam antes de escrever, escrevem porque pensam (raros). Preocupado com essa relação entre escrita e pensamento, ele ainda desdobra essa questão em relação à ciência. Há os que vivem para a ciência, que produzem com seriedade, tranquilidade e lentidão uma literatura que permanece; e há os que vivem da ciência, que produzem com estardalhaço, balbúrdia e pressa uma literatura passageira. Ele ainda complementa: os primeiros produzem com muita qualidade e em pouca quantidade, ao contrário dos últimos, que produzem muito, mas com pouca qualidade (SHOPENHAUER, 2013, p. 134-5). Isso foi dito há quase 200 anos e decerto já não era nenhuma novidade.

Igualmente não é novidade para ninguém que a avaliação da produção científica se baseia na literatura especializada, especificamente nos artigos científicos, que cada vez mais vêm sendo tratados como mercadoria, desenhando um cenário desolador de produtivismo acadêmico. Em geral, os critérios quantitativos se sobrepõem aos qualitativos por sua ligeireza, afinal, é muito mais rápido contar quantos artigos determinado pesquisador escreveu, ou quantas vezes ele foi citado, e onde, do que ler todos os seus artigos cuidadosamente e avaliá-los qualitativamente. Evidentemente, isso se transforma num círculo nada virtuoso, já que o pesquisador é incentivado a publicar muito, o que nem sempre significa publicar textos bons e relevantes. O produtivismo acadêmico, a aceleração das ciências e os métodos quantitativos envolvidos nesse processo têm sido objeto de diversas críticas, dossiês e manifestos (STENGERS, 2013; MENDONÇA, 2014; GOMES; CUNHA; PALLONE, 2015). A revisão por pares, processo característico da prática científica desde os primeiros periódicos no século XVII (FIORAVANTI, 2015, p, 75), que pretende ser autônoma e se autorregular, e que deveria ser a contraparte qualitativa dessa avaliação, vem se enfraquecendo e ganhando alguns detratores (FULLER, 2006; ARNS, 2014; THELVAL, 2014).

A esse quadro problemático, acrescentarei aqui mais um elemento: a autoria científica. A autoria coletiva, colaborativa e em rede chegou para ficar, e por vários motivos para além dos novos recursos tecnológicos, entre eles inclusive o problema do produtivismo mencionado anteriormente, já que escrever em parceria multiplica as possibilidades de publicação. Mas não é só esse ponto que me interessa, e sim o próprio conceito de autoria científica, já que ele está atrelado à questão da avaliação, tendo em vista que só se pode avaliar uma produção devidamente assinada. Mas além da atribuição de crédito, desse reconhecimento necessário em processos avaliativos, a autoria também viabiliza responsabilizações, ao contrário de textos anônimos ou não assinados. Voltando a Schopenhauer (2013, p. 73), “[...] o anonimato serve apenas para tirar toda a responsabilidade daquele que não pode defender o que afirma [...]". Por outro lado, a autoria científica também carrega essa marca do anonimato, da imersão num discurso que circula numa certa circunstância, tendo em vista que a ciência é uma empreitada coletiva tributária de um determinado tempo-espaço que, nos termos de Michel Serres (1996, p. 144), nem sequer se trata de um conteúdo, e sim de um modo de circulação. Ou seja, as noções de autoria e de avaliação em ciência precisam ser investigadas.

Diante disso, a questão que me servirá de fio da meada neste artigo será a seguinte: como pensar a avaliação da ciência e a autoria científica a partir da afirmação de Serres em epígrafe? Minha hipótese é de que, 
partindo da ideia de ciência como modo de circulação, o conceito de autoria científica muda drasticamente, produzindo em alguns casos até a eliminação de autoria individual (KNORR-CETINA, 1999, p. 389-90), o que nos aproxima das teorias da recepção e da própria "morte do autor" (BARTHES, 1968), como nos lembra a frase de Woolf em epígrafe. Diante disso, os critérios de avaliação da produção científica precisam ser revistos. Parece-me devidamente justificada essa proposta, tendo em vista a sua contribuição para uma discussão mais ampla que se tem avolumado nos últimos anos e que reúne produtivismo acadêmico, autoria científica e critérios de avaliação. O objetivo deste texto, portanto, é demonstrar a hipótese formulada acima por meio de uma reflexão sobre o tema, tomando os science studies como base teórico-metodológica e uma série de exemplos e estudos de caso, como a autoria Darwin-Wallace, o selfie da macaca e os autômatos. Para realizá-lo, começarei definindo a literatura científica, sobretudo a partir de Bruno Latour (1987). Na sequência, desdobrarei um pouco a questão da literatura em relação às métricas atuais e alternativas com base em discussões recentes (MARQUES, 2013; THELVALL, 2014; ALLEN et al., 2014; MENDONÇA, 2014). Para finalizar, tratarei da autoria científica (BIAGIOLI, 2003; GALISON, 2003; CHARTIER, 2003) em diálogo com questões de autoria em rede (MARTINS, 2014) e também com o conceito de autoria em Michel Foucault (1969; 1970; 1983).

\section{Literatura científica}

Em seu livro Ciência em ação, Latour (1987) começa pela literatura a sua jornada com "cientistas e engenheiros sociedade afora" a fim de produzir uma imagem de ciência mais realista, mais próxima da prática. Não é difícil imaginar o estranhamento que isso pode causar num leitor desavisado, ainda mais quando vê que o capítulo a seguir vai tratar dos laboratórios, e que ambos compõem a primeira parte, chamada "Da retórica mais fraca à mais forte". Literatura como retórica ainda vá lá, mas laboratórios não, esse mesmo leitor poderia pensar. Decerto, esta não foi uma decisão impensada de Latour. Estrategicamente, ele começa apelando ao senso comum, partindo da ideia familiar de que a literatura, ainda que científica, está repleta de retórica, de recursos de convencimento que são mobilizados das mais diversas formas. Na sequência, ele introduz a novidade: os laboratórios igualmente mobilizam esses recursos, e constituem uma "retórica mais forte".

Nesse cenário, o número de atores da prática científica se multiplica para além de cientistas e engenheiros, e as barreiras entre ciência e sociedade, racional e irracional, objetivo e subjetivo, teoria e prática, entre outras, não fazem mais sentido. Muitos que estão dentro saem, é preciso "vender o peixe", arrumar dinheiro, mobilizar a indústria e outros aliados, fazer política, administrar a pesquisa etc. Com isso, as redes científicas ampliam suas fronteiras, tornando obsoleto o rótulo "ciência e tecnologia". Latour passa a usar o termo tecnociência para indicar essa prática híbrida e coletiva que produz e estabiliza os chamados fatos e artefatos científicos, afastando-se da noção de uma natureza a ser revelada e de uma "ciência e tecnologia" produzida por poucos escolhidos que são capazes de entender as "leis imutáveis da natureza" e que se baseia na distinção entre interno e externo, considerando evidentemente o que é interno à ciência como racional e objetivo, enquanto o externo é irracional e subjetivo. A antropologia simétrica de Latour se propõe a romper com essa distinção entre internalismo e externalismo, tratando ciência e sociedade nos mesmos termos, o que não significa que suas redes sejam compostas de elementos iguais. Em vez de grandes divisores, vislumbra-se, por meio da teoria ator-rede, descrever o mundo pelas suas interações.

Meu objetivo aqui não é discutir retórica, os laboratórios ou a estratégia de Latour. Interessa-me tomá-lo como pretexto para analisar a questão da literatura científica não só mais como meio de circulação do conhecimento (produção, transmissão, educação, divulgação), ou como parte da prática científica junto com os laboratórios (métodos, modelos etc.), mas também no seu desdobramento como meio de avaliação da ciência, que se baseia no conceito de autoria para responsabilizar e reconhecer a produção científica.

A literatura científica inclui textos de vários tipos, como livros, artigos, cartas, ensaios, projetos de pesquisa, teses e relatórios. Desse conjunto, o artigo científico se sobressai não só como meio de comunicar resultados de pesquisas, mas como mercadoria (CASTIEL et al., 2011). É o artigo que vai servir como moeda de troca do pesquisador para conseguir financiamento, ser reconhecido pelos pares, ter boa pontuação em 
concursos e outras avaliações etc. Como qualquer moeda, quanto mais artigos ele tiver e mais citado for, mais bem-avaliado será. Nesse contexto, ser produtivo significa produzir muito, e não necessariamente bem. Claro que há variações sobre esse tema, já que nem todos os periódicos que veiculam esses artigos têm o mesmo valor, e que há realmente pessoas que produzem muito e bem, sem problemas, mas nem todos são ou deveriam ser assim, e isso não muda o quadro do produtivismo com enfoque na quantidade, em vez de na qualidade.

Em sua análise do artigo científico, Latour (1987, p. 45-65) apresenta três estratégias gerais que costumam ser usadas nesse tipo de literatura para estabilizar fatos que estão sendo construídos em meio a controvérsias: 1) arregimentar amigos (quanto mais aliados, mais capacidade de convencimento); 2) reportar-se a textos anteriores (usando-os a seu favor); e 3) ser tomado como referência por textos posteriores. Vale lembrar que Latour aqui não elabora exatamente uma "teoria das controvérsias", como se pode ver, por exemplo, em Collins (1999) e Dascal (1999). Ele está preocupado em mostrar como se produz e se estabiliza um fato científico, ou seja, em como uma controvérsia - seja ela de que tipo for - se transforma em caixa-preta, e no papel da literatura científica nesse processo. Ele ainda fala em análise do "contexto de citação" (LATOUR, 1987, p. 51), que pode revelar os usos dos textos alheios para fortalecer suas próprias teses, e diz que as regras são simples e equivalem às "regras dos velhos políticos" (LATOUR, 1987, p. 55). São elas:

\section{Enfraquecer os inimigos;}

Paralisar os que não podem ser enfraquecidos;

Ajudar os aliados caso sejam atacados;

Garantir comunicações seguras com as fontes inquestionáveis;

Fazer os inimigos brigarem entre si;

Fazer declarações atenuadas caso a vitória não seja certa.

Qualquer semelhança com Maquiavel não é mera coincidência. Dessa atividade "maquiavélica" do artigo científico, que implica citar e ser citado, surge toda uma abordagem de avaliação em ciência, como os índices de citações, que veremos na próxima seção. Nesse cenário, ser criticado é melhor do que ser mal citado, que, por sua vez, é melhor do que ser ignorado.

Vale lembrar que um texto, depois de publicado, ganha vida própria e, da mesma forma que ele usa textos alheios a seu favor, o mesmo pode acontecer na sua trajetória. Por isso, nesse processo de construção coletiva de um fato, a literatura científica vai se especializando cada vez mais, mobilizando cada vez mais gente e fortalecendo seu discurso a fim de estabilizar o fato em questão e afastar a controvérsia. Segundo Latour (1987, p. 65-88), a literatura vai ficando cada vez mais técnica e estratificada para se proteger. Além do autofortalecimento (por meio de autorreferência a outros textos do autor, mas sobretudo ao próprio texto, com figuras, tabelas, gráficos, fotos, legendas), há três táticas para escrever textos com esses recursos todos e que resistam à hostilidade: 1) empilhamento; 2) encenação e enquadramento; e 3) captação.

O empilhamento equivale a uma construção de pedra: são camadas que vão se sobrepondo, mas acrescentando algo à anterior. Por isso, nunca se deve empilhar uma camada exatamente sobre a outra, seria pura repetição. Tampouco se devem queimar etapas, saltando da primeira para a última camada. Ademais, devese fazer o máximo com o mínimo, ou seja, não ser tímido demais nem ousado demais (LATOUR, 1987, p. 76). A encenação e o enquadramento são criados pelo autor para produzir reações específicas no leitor. Para isso, além da escolha do jargão apropriado, há que se prever as possíveis objeções desse leitor-alvo. Na esteira da "pluralidade de eus" de Foucault (1969, p. 55-6), Latour aqui distingue os "autores de carne e osso" dos "autores no papel", e diz que "como parte da escrita do enredo, não se conta quem escreveu o enredo", e que a atribuição e a ordem da autoria fazem parte da encenação (LATOUR, 1987, p. 80). A captação é a terceira e última tática, e parte do princípio de que o "leitor é gente escorregadia, obstinada e imprevisível" (LATOUR, 
1987, p. 84). Daí para a metáfora leitor-água e que, portanto, desliza pelo texto é um pequeno salto. O processo de convencimento do leitor seria, então, como a construção de barragens a fim de direcionar essa água. Quando tudo dá certo e a captação dessa "água" funciona, o texto é considerado lógico, técnico ou científico, dando a impressão de ser uma literatura especial escrita por gente genial com métodos rigorosos sobre fatos estáveis, e não o que realmente é: um conjunto de esquemas práticos cuja eficiência depende tanto do autor quanto do leitor. Latour, aqui, ecoa as ideias de Roland Barthes (1968) sobre a "morte do autor" que, entre outras questões, implica o foco no leitor, no polo receptor.

Dito isso, vejamos agora como os artigos científicos costumam ser avaliados.

\section{Avaliação bibliométrica das ciências}

Há algo que logo chama a atenção em relação à avaliação científica: a natureza, a verdade e o conteúdo produzido pelas ciências são cada vez mais secundários. O que importa, como vimos na seção anterior, são os artigos, a sua quantidade, em que periódicos são veiculados e o quanto são citados. A comunidade científica valoriza a produção de artigos, transformando-a em seu principal objetivo, e considera que pesquisador competente é pesquisador produtivo em termos quantitativos, não sobrando muito espaço para a originalidade (típica ciência normal kuhniana). Com isso, como vimos anteriormente em Latour, o cientista começa a investir em propaganda e estratégias que lhe sejam mais vantajosas para o currículo e a carreira, mesmo que isso signifique sair do laboratório².

Já que falamos em currículos, os modelos padronizados - no caso do Brasil o currículo Lattes - servem para armazenar e contabilizar todas essas informações. O Lattes, como ele é chamado abreviadamente, é pré -requisito para um pesquisador (e hoje em dia até mesmo um aluno de graduação) conseguir qualquer coisa no meio acadêmico. A avaliação é constante não só em situações de concurso, financiamento, seleção, entre outras, mas também no cotidiano para, por exemplo, conhecer melhor um professor, aluno, pesquisador, colega ou detrator. As próprias instituições, universidades e programas de pós-graduação fazem uso desse recurso para ajudar nas tomadas de decisões sobre políticas a serem desenvolvidas interna e externamente.

Em relação às métricas de avaliação da literatura, chamadas bibliometrias, alguns dos índices que costumam ser tomados como parâmetro para definir o mérito do pesquisador são os seguintes: fator de impacto (do periódico), número de artigos, número de citações, citações por artigo, número de artigos altamente citados $\mathrm{e}$, mais recentemente, o índice $\mathrm{h}$. Acredito que todos sejam autoexplicativos, exceto o último. O índice $\mathrm{h}$ tem sido considerado por alguns como uma panaceia para todos os males avaliativos por supostamente juntar quantidade e qualidade. Ao mesmo tempo que se mede a produtividade do pesquisador, mede-se também o impacto do seu trabalho. O que é o índice h? Trata-se do maior número (h) de artigos publicados por um(a) pesquisador(a) que tenha sido citado pelo menos esse mesmo número (h) de vezes. Ou seja, se ele(a) publicou 100 artigos, e cada um deles foi citado em 100 outros trabalhos, seu índice h será 100. Mas há controvérsias sobre o uso desse índice sem considerar os outros, sem considerar as diferenças entre os vários campos do conhecimento, sem considerar o contexto de citação, entre outras. A crítica que mais me interessa aqui diz respeito à autoria. Esse índice não faz distinção entre um(a) pesquisador(a) individual, um pequeno grupo ou um grande coletivo científico, pois não é possível medir quem fez o quê no caso de uma colaboração. Por conta dessa limitação, já há quem defenda que seria mais prudente não contabilizar esse tipo de artigo, indo totalmente na contramão da história (MARQUES, 2013). Mas há igualmente os que se preocupam em identificar os tipos de colaboração em projetos colaborativos (ALLEN et al., 2014; FRISCHE, 2012).

2 Ziman (1999) define essa transformação como a passagem da ciência acadêmica para a ciência industrial, que se caracteriza sobretudo por uma mudança no ethos científico, que, na ciência acadêmica, se baseia na busca pelo prestígio (CUDOS) garantido pelas cinco "normas" mertonianas (Comunalismo, Universalismo, Desinteresse, Originalidade e (S)ceticismo), e que, na ciência industrial, se baseia na busca de uma posição (PLACE) hierárquica bem remunerada, governada por "normas" bem diferentes (Propriedade, Localidade, Autoridade, Comissão e Especialização). Uma das consequências dessa mudança é que o conhecimento vai deixando de ser público e se tornando privado. Para saber mais sobre essa passagem, além da obra de Ziman, recomendo a leitura de Reis \& Videira (2013). 
Há também questões específicas em situações de ciência periférica, como é o caso do Brasil (CAMARGO JR.; COELI, 2012; CASTIEL et al., 2011), que acaba adotando os modelos (teórico-metodológicos, instrumentais, avaliativos etc.) hegemônicos, apesar de não fazer parte do mesmo "clube", o que gera um estranhamento ainda maior. Mesmo quem faz parte do clube não anda lá muito satisfeito com a situação. Um exemplo disso é a declaração DORA (Declaration on Research Assessment) ${ }^{3}$, que afirma, por meio de uma recomendação geral (de não usar métricas como o fator de impacto para avaliar os pesquisadores) e 17 específicas (divididas em cinco categorias: pesquisadores, instituições de pesquisa, editores, agências de fomento, organizações que fornecem métricas), a necessidade de melhorar as formas de avaliação científica. Trata-se de uma empreitada mundial, iniciada em dezembro de 2012 pela Sociedade Americana de Biologia Celular e um grupo de editores, e que cobre todas as áreas acadêmicas. Até o momento (novembro de 2016), 12.583 pessoas e 916 instituições já assinaram a declaração. Outro caso é o movimento slow science, que reage à chamada fast science, ou seja, essa ciência apressada regida por produtivismo, números e índices bibliométricos, que não reserva tempo para o trabalho tipicamente científico, que não pode ser imediatista, pois exige tempo para reflexão, discussão e digestão. Esse movimento de desaceleração da ciência se insere num contexto mais amplo de desaceleração de outras práticas contemporâneas movidas pela competitividade e pela globalização. Um exemplo dessas práticas é a reação, a partir dos anos 1980, à fast food, que deu origem ao movimento slow food ${ }^{4}$.

Antes de finalizar esta seção, vale lembrar outro tipo de literatura científica que também costuma ser objeto de avaliação: os projetos de pesquisa. Não se faz uma pesquisa sem projeto. É ele, por exemplo, que é submetido às agências de fomento para se conseguir um financiamento ou uma bolsa de pesquisa em qualquer nível. Nas universidades públicas, em geral, é o projeto de pesquisa que vai definir se o docente tem ou não dedicação exclusiva. É também com base num projeto de pesquisa que os alunos de graduação conseguem ou não fazer uma iniciação científica. Ademais, nesse campo da elaboração de projetos cada vez mais a produção tem se mecanizado, e o que se vê é a multiplicação de projetos que atendem a demandas e agendas que não as dos próprios pesquisadores. Ao atender a interesses de governos, da indústria, de qualquer outra instituição, ou do próprio orientador, o que se vê, para além da avaliação, é o controle da pesquisa e de seus resultados. Mas este é um outro problema que não será tratado aqui, fica só registrado o ponto.

Em qualquer um dos casos, além de todas as características intrínsecas a um projeto, entra em jogo o tempo como item de controle. Na apresentação de uma pesquisa, a sua duração é o fator determinante mais objetivo para os avaliadores definirem se o projeto é viável, além da parte financeira, se for o caso. No entanto o fator tempo acaba sendo também determinante na pressa com que se faz um parecer, podendo impactar negativamente na contrapartida qualitativa da avaliação, que é a revisão por pares. Evidentemente isso serve também para pareceres em periódicos. Os "pares" estão cada vez mais assoberbados com suas tarefas cotidianas em busca das metas numéricas estabelecidas em sua área, que acabam produzindo pareceres pro forma ou sem sentido.

Um caso recente talvez seja um exemplo disso ou de coisa pior. Em poucas palavras, sou coordenadora de um grupo de pesquisa em science studies, que, em 2013, conseguiu aprovar um projeto no Edital de Ciências Humanas do CNPq. O grupo pediu financiamento de custeio e capital, mas só conseguiu o custeio. Em 2014, um outro projeto, continuação do anterior, foi enviado para o Edital Universal da mesma agência. O projeto foi indeferido com o seguinte parecer:

Embora seja continuação de projeto financiado pelo CNPq (há 2 anos), pretendendo investigar o discurso da ciência na perspectiva da história das disciplinas científicas ('Science Studies') [sic], o projeto não é claro e não demonstra relações possíveis com o estudo em tela [sic] com a contemporaneidade, o que é relevante face ao desenvolvimento da ciência presente. Com efeito, a física de hoje, em áreas com a Gravitação Quântica [sic], dificilmente se enquadrariam em tais Studies [sic].

3 Para obter mais informações, cf. http://ascb.org/dora/.

4 Cf., por exemplo, http://slow-science.org/ e o manifesto de Isabelle Stengers (2013), Uma outra ciência é possível! 
Diante de tal insólito parecer, solicitei uma reconsideração nos seguintes termos:

Gostaria de solicitar uma reavaliação do projeto, tendo em vista que parece ter havido algum engano. Em primeiro lugar, há uma certa contradição da própria agência, tendo em vista que o projeto é continuação de outro, que foi considerado devidamente claro e pertinente. Além disso, o projeto não diz que o campo dos Science Studies é o mesmo da história das disciplinas científicas, como o parecer faz crer. O projeto também não fala de física ou gravitação quântica, então por que isso é mencionado no parecer? (Aliás, vale o esclarecimento de que os principais trabalhos dos Science Studies são justamente na área da física.) E, para finalizar, "tais Studies" soa, na melhor das hipóteses, como um tratamento pejorativo para um campo de conhecimento que, como é dito no projeto, pretende aproximar ciência e sociedade numa perspectiva interdisciplinar. Será que pesquisar essa relação entre ciência e sociedade, por si só, já não seria um objetivo relevante para um projeto de pesquisa apoiado pelo $\mathrm{CNPq}$ ? Ou será que está tudo perfeito nas políticas científicas, na distribuição de recursos, nas avaliações de produção, no acesso público ao conhecimento etc.? A meu ver, ao contrário, poderíamos nos perguntar a quem não interessa essa discussão?

Depois de alguns meses, o processo foi reavaliado pelo CNPq e, conforme o previsto, continuou indeferido, mas vale aqui como exemplo da situação da avaliação qualitativa no atual estágio das políticas científicas ${ }^{5}$.

Esse tipo de problema não ocorre só no Brasil e essa questão da pressa e do produtivismo tem sido discutida por toda parte, como se pode ver em outro caso, que obteve destaque na grande imprensa no fim de 2013. Trata-se da declaração do físico britânico, Peter Higgs, alguns meses depois de receber o prêmio Nobel, sobre o produtivismo do mundo acadêmico atual, que se caracteriza pela produção de artigos em grande quantidade a despeito da qualidade. Higgs tem 85 anos, aposentou-se em 1996 e diz que, se fosse hoje, não teria o tempo e a tranquilidade suficientes para fazer o que fez em 1964, quando identificou o mecanismo pelo qual o material subatômico adquire massa. Na verdade, ele acha que nem conseguiria o emprego, pois seria considerado improdutivo. Vale lembrar que, depois disso, ele publicou menos de 10 artigos $^{6}$.

Diante desse quadro melancólico, algumas iniciativas têm surgido no campo da discussão da bibliometria. Além da já mencionada declaração DORA, uma publicação exclusivamente dedicada a essa questão, a Research Trends, é um exemplo disso. Em seu número 37, de junho de 2014, trouxe à tona uma discussão sobre métricas alternativas, a chamada altmetria ${ }^{7}$. Seu princípio é de que, diante da nova realidade de compartilhamento na internet, as redes sociais devem ser levadas em consideração para medir o impacto e o uso da produção acadêmica (THELVALL, 2014). Há um manifesto na web pela altmetria ${ }^{8}$. Ele parte do truísmo "ninguém pode ler tudo", então precisamos de filtros, e avança na direção de criticar os atuais filtros (revisão por pares, contagens de citações e fator de impacto) e de propor melhorias via altmetria.

Importante mencionar aqui também a análise do meu amigo André Mendonça (2014), não para citar amigos a esmo e aumentar os índices bibliométricos deles, mas porque seu artigo-ensaio é deveras relevante para toda essa questão, a começar pelo título, Dos valores de medida aos valores como medida: uma avaliação axiológica da avaliação acadêmica. Apesar de o texto ter sido construído a partir do diagnóstico de uma doença (SOMA - Síndrome da Ostensiva Mercantilização Acadêmica), da apresentação dos seus sintomas e causas, já no título ele prescreve o tratamento: precisamos de mais valores. Para isso, evidentemente, é necessário (re)inverter os valores vigentes: em vez de critérios quantitativos (que não deixam de ser um valor), devemos investir em critérios qualitativos, tomar os valores como medida. O sentido de valor é cuidadosamente definido por ele:

5 Ambos os projetos e pareceres se encontram disponíveis no blog do grupo: https://gpsciencestudiesuem.wordpress.com/, mas, a título de registro, a página de apresentação do segundo se encontra no Anexo 1.

6 Cf. http://www.theguardian.com/science/2013/dec/06/peter-higgs-boson-academic-system.

7 Cf. http://www.researchtrends.com/category/issue-37-june-2014/.

8 Cf. http://altmetrics.org/manifesto/. 
[...] valores são referenciais responsáveis pela coesão social, em função justamente das questões de sentido para as quais eles nos orientam. Desse modo, esteja bem claro desde já que aqui valores não se limitam à esfera dos preceitos morais, tampouco dos 'gostos pessoais'; na realidade, nós temos de valores estéticos a éticos, passando por valores epistêmicos e políticos: valores sendo, portanto, nossas crenças, interesses e compromissos compartilhados mais recônditos, carregados de sentido e condicionantes do nosso conhecer (ciência/humanidades), sentir (arte/religião), agir (ética/direito), decidir (política) etc., cuja grande característica consiste na lacuna essencial entre o norte que projetamos e o lugar em que efetivamente estamos (MENDONÇA, 2014, p. 114-5).

Evidentemente que isso não se faz de imediato e sem luta.

Vistas as questões da literatura científica e da avaliação em ciência, chegou a hora de encarar o problema da autoria.

\section{0 problema da autoria em ciência}

Amparada nos problemas de autoria científica propostos no livro editado por Mario Biagioli e Peter Galison $(2003)^{9}$, especialmente no que diz respeito à questão do crédito e da propriedade intelectual em ciência, pretendo me ater à questão de base: quem são os autores científicos? Serão os próprios atores da prática científica, todos aqueles elencados por Latour, cujo conjunto se estende muito além dos próprios cientistas? Serão os porta-vozes? Ou será que as categorias de colaboradores, fiadores, patronos e aliados, embora componham os coletivos científicos, nada têm a ver com os autores científicos? Será que cada campo da ciência trabalha com um diferente conceito de autor? Será que o problema da autoria em ciência é similar ao da autoria em literatura?

Proponho agora avançar um pouco a partir da trilogia “O que é um autor?", "A ordem do discurso" e "A escrita de si", de Michel Foucault (1969; 1970; 1983), na qual ele diz que o problema não é similar, tendo em vista que quando a questão da autoria começa a prevalecer na literatura (séculos XVII e XVIII), nas ciências se impõe o anonimato da imersão num sistema. Ou seja, o nome do autor, a autoridade, não garante mais a verdade das ciências, e sim a sua reprodutibilidade, a sua capacidade de ser constantemente demonstrada (FOUCAULT, 1969, p. 49), como em "um teorema, um efeito, um exemplo, uma síndrome" (FOUCAULT, 1970, p. 27). Aqui parece que o conceito de autoria científica não tem necessariamente a ver com a autoria de um texto científico, e sim com a autoria de ideias, teorias, práticas ou experimentos científicos. Nos termos de Foucault (1983, p. 144), esta talvez seja a função etopoiética da escrita, ou seja, de transformar verdade em ethos, constituindo um corpo. No caso em questão, o próprio corpo científico, tanto em termos de conteúdo quanto de campo de conhecimento com sua respectiva comunidade. "Ela se torna no próprio escritor um princípio de ação racional." (FOUCAULT, 1983, p. 149).

Sobre isso, vejamos um caso bem conhecido de meados do século XIX: a autoria da teoria da evolução por seleção natural, que costuma causar celeuma entre os historiadores. Pelos mais diversos motivos, que não me cabe explorar aqui e agora, alguns consideram a autoria da teoria como sendo de Alfred Russel Wallace (1823-1913), outros de Charles Robert Darwin (1809-1882), e há ainda os que consideram a dupla autoria (PAPAVERO; SANTOS, 2014; VAN WHYE; ROOKMAAKER, 2012). Evidentemente ninguém discute a autoria dos respectivos textos iniciais, que foram devidamente assinados e apresentados juntos publicamente pela primeira vez no dia 1 de julho de 1858 na Sociedade Linneana de Londres nem por um nem por outro, mas sim por John Hooker e Charles Lyell (cf. Anexo 2). Ambos foram testemunhas, junto com Thomas Huxley e Asa Gray, todos naturalistas reconhecidos, de que Darwin já trabalhava na teoria há cerca de 20 anos quando recebeu pelo correio o ensaio de Wallace que precipitou os acontecimentos, só não tinha tido coragem ainda de publicar, apesar dos recorrentes apelos de seus amigos.

9 Todas as traduções de citações diretas deste livro e de outros textos não traduzidos são de minha autoria. 
Todos esses testemunhos, além de cartas e cadernos de notas de Darwin, bem como um rascunho (1842) e um ensaio (1844), contam um pouco dessa história. Segundo uma de suas biógrafas, Janet Browne (2003, p. 96): "Sem essa extraordinária correspondência, que chegou a 500 cartas por ano depois da publicação da Origem das espécies, a teoria de Darwin teria ido a pique." Sobre os cadernos, diz ela: "Darwin começou a registrar o turbilhão de idéias em uma série de cadernos pessoais que rotulou de A a E, e depois de E a M e N, hoje conhecidos como 'cadernos da transmutação'” (BROWNE, 2003, p. 49). E sobre a participação de seus amigos no processo:

Quatro amigos de Darwin suportaram o impacto da tempestade pública [...]. Enquanto Darwin ocupava-se em escrever cartas nos bastidores, os quatro recrutaram um exército permanente, apropriaram-se de jornais, invadiram sociedades cientificas, monitoraram universidades, dominaram os jantares e penetraram nos recônditos do império. A oposição nunca chegou a se consolidar da mesma maneira. [...] A existência dessa aliança em torno das idéias de Darwin talvez tenha sido a característica isolada mais importante do debate e contribuiu acentuadamente para o triunfo final da teoria evolucionária. Em seu núcleo estavam Charles Lyell, Joseph Hooker, Asa Gray e Thomas Henry Huxley (BROWNE, 2003, p. 97-8).

Ou seja, apesar de recluso, Darwin está longe de ter sido um cientista solitário. Trocava cartas com outros naturalistas, criadores, jardineiros, militares, diplomatas e colaboradores de todos os tipos ao redor do mundo. Por meio dessas missivas, ele incrementava sua base empírica, elaborava hipóteses, discutia teorias, planejava experimentos, fazia propaganda, elaborava estratégias para a circulação de seus textos, tirava dúvidas de tradutores, aumentava sua base de aliados e criticava seus detratores, fortalecia suas táticas de convencimento, enfim, fazia e circulava ciência no sentido de Latour e Serres. Tudo isso foi usado no seu trabalho. No total (incluindo cartas particulares e familiares), foram cerca de 2 mil correspondentes em cerca de 15 mil cartas. Só com Wallace, até onde pude apurar, houve uma troca de 189 cartas de 1857 a $1881^{10}$.

Em 1859, finalmente Charles Darwin publicou a primeira edição do seu famoso livro, Origem das espécies, que teve mais cinco edições $(1860,1861,1866,1869,1872-1876)$ ao longo de sua vida. Desde a primeira, Darwin se preocupou em estabelecer a anterioridade do seu trabalho, fazendo menção à apresentação conjunta de seu texto junto com o de Wallace no ano anterior. Por meio da leitura de suas cartas ${ }^{11}$, é fácil mapear essa anterioridade, bem como a preocupação de Darwin com o assunto. ${ }^{12}$ Nesse caso, a questão da autoria em ciência (pelo menos no sentido textual), ao contrário do que disse Foucault, não me parece tão disposta ao anonimato, muito embora também não tenha o mesmo sentido de autoridade de tempos pregressos.

Nessas mesmas cartas, também não é difícil perceber a amizade entre Darwin e Wallace, inclusive com menções à coautoria, bem como as diferenças teóricas que vão se constituindo com o tempo. Pouco depois da morte de Darwin, Wallace publicou o que, para muitos, é o melhor texto sobre seleção natural do século XIX, que chamou de Darwinismo, recentemente traduzido para o português. ${ }^{13}$ Pelo título se percebe a reverência que ele faz a Darwin, no entanto não se trata de um elogio, e sim da sua própria apresentação da teoria da evolução por seleção natural, apesar de Wallace o ter convencido de não usar mais o termo "seleção natural". Não cabe aqui analisar essas diferenças, mas, segundo Browne:

10 Boa parte da correspondência de Darwin já se encontra disponível para consulta online no site http://www.darwinproject. ac.uk/.

11 Só para citar algumas trocadas com o próprio Wallace: cartas 2086 e 2192 de 1857; e cartas 2405, 2449, 2480, 2529. Há outras cartas tratando do assunto, sobretudo com seus amigos mais próximos, que merecem uma pesquisa mais cuidadosa.

12 Há um filme de 2009, Darwin's darkest hour, que tem como foco justamente a tensão entre Darwin e Wallace. A direção é de John Bradshaw, o roteiro, de John Goldsmith, e a produção, da National Geographic Television para a NOVA. O título em português ficou A tormenta de Darwin, e o filme é facilmente encontrado no Youtube.

13 WALLACE, Alfred Russel. Darwinismo: uma exposição da teoria da seleção natural com algumas de suas aplicações. Tradução de Antonio Danesi. SP: EdUSP, 2012. Encontra-se o texto original, de 1889, digitalizado no arquivo Wallace na internet: $<$ http://wallace-online.org/>. 
A principal divergência entre eles dizia respeito à origem dos seres humanos. [...] [Wallace] declarou que a seleção natural era insuficiente para explicar todos os começos evolucionários do homem. Propunha, em vez disso, que a seleção natural tivesse levado nossos ancestrais simiescos apenas até o limiar do gênero humano. Nesse ponto, a evolução física teria cessado e uma outra coisa assumido o controle: o poder da mente. [...] Apesar de todos os seus genuínos princípios democráticos, Wallace acreditava em uma hierarquia de selvagens e civilizados. Darwin ficou desconcertado: 'Espero que você não tenha assassinado completamente o seu próprio filho e também o meu' (BROWNE, 2003, p. 118-9).

Essa última passagem é de uma carta de Darwin a Wallace (carta 6684) e é importante porque, além de demonstrar a naturalidade com que ele tratava essa coautoria, aponta para uma deriva indesejada das suas ideias para a sociobiologia ou o que viria a se chamar darwinismo social. Darwin não concordava com isso, mas não pôde fazer nada para evitar, afinal, como já foi dito antes, depois de publicadas, palavras e ideias não mais pertencem a seus autores. Suas ideias, mescladas com as de Wallace, foram tomadas por Spencer, Galton, entre outros, que as usaram para seus próprios fins, e o desfecho derradeiro disso são coisas como a eugenia, as teorias raciais e outras mazelas afins. Ou seja, o nome de Darwin acabou sendo associado a uma linha de pensamento da qual ele não foi autor. ${ }^{14}$

Há outras cartas similares em que ele menciona a coautoria seja da teoria como um todo (carta 4510), seja de alguns conceitos, como "sobrevivência dos mais aptos", originalmente de Herbert Spencer, mas sugerida por Wallace a Darwin em substituição à "seleção natural” (carta 5145); e também das diferenças que foram se avolumando com o tempo (carta 6095). Mas estes são só alguns exemplos, uma pesquisa mais sistemática nessas cartas ainda está por ser feita.

Tendo em vista o caso Darwin-Wallace e voltando a Foucault, apesar da suspeita sobre a precisão da sua interpretação de autoria científica como anonimato a partir do século XVII ou XVIII, ele propõe alguns pontos que me parecem ser instrumentais para o que aqui estou tratando, como a questão da responsabilidade e do reconhecimento. Há controvérsias sobre essa leitura de Foucault (CHARTIER, 2003), mas vamos tentar entendê-la primeiro.

A função-autor é definida como "característica do modo de existência, de circulação e de funcionamento de alguns discursos no interior de uma sociedade" (FOUCAULT, 1969, p. 46), e tem os seguintes traços: 1) forma de propriedade (o discurso passa de ato a bem, sendo sujeito à punição); 2) ação inconstante e não universal sobre os discursos (diferença, por exemplo, entre textos literários e científicos, que, na antiguidade e no medievo eram respectivamente anônimos e autorais, mas que, na modernidade, invertem seus papéis); 3) formação complexa, que pretende ser racional e realista, mas que é só projeção de como se aborda o texto; e 4) pluralidade de “eus" (autor $\neq$ escritor real), como já vimos em Latour anteriormente (autor de carne e osso $\neq$ autor no papel).

Outra figura que Foucault associa ao autor, a partir do século XIX, é a de instaurador de discursividade. Ele ainda vai mais longe e diz que "a instauração de discursividade parece ser do mesmo tipo da fundação de qualquer cientificidade" (FOUCAULT, 1969, p. 61), o que implica uma equivalência discurso-ciência, mas sobretudo a possibilidade de produzir diferenças, além de igualdades, analogias e repetições. Ou seja, as transformações decorrentes de uma instauração de discurso científico também fazem parte desse discurso. No caso do darwinismo, por exemplo, o fato de sua teoria ter sido modificada, ou recebida de maneira enviesada em certos contextos, faz parte dessa cientificidade. E mais, não é o texto de Darwin ou de qualquer outro instaurador que se situa numa ciência, e sim o contrário: "é a ciência ou a discursividade que se relaciona com a obra deles e a toma como primeira coordenada" (FOUCAULT, 1969, p. 63). Ou, seja, trata-se de uma atividade constante de redescoberta, reescrita, reconstrução, reatualização, "uma costura enigmática da obra e do autor" (FOUCAULT, 1969, p. 66), como em Barthes, Serres e Latour, com suas respectivas teorias da recepção, da circulação e ator-rede.

14 Sobre como isso se desdobrou entre nós, cf. o excelente livro A recepção do darwinismo no Brasil publicado pela Editora da Fiocruz e organizado por Heloisa Maria Bertol Domingues, Magali Romero Sá e Thomas Glick (2003). 
A questão da autoria ainda se complica mais quando se fala em obra, grupos de obras ou disciplinas. Por essas e por outras, Foucault defende um estudo dos discursos, retirando do sujeito "o papel de fundamento originário e de o analisar como uma função variável e complexa do discurso" (FOUCAULT, 1969, p. 70). Assim se poderia pensar em discursos circulando sem função-autor, no "anonimato do murmúrio". Mas o que se ganha com isso?, poderia o leitor perguntar. A meu ver, a desmistificação relacionada a grandes gênios solitários, intenções do autor ou verdades definitivas. Todo texto é aberto a interpretações e se constrói sobre outros, como um palimpsesto. O mesmo se pode ver - e com ainda mais clareza por conta do maior distanciamento temporal -, por exemplo, na obra de Aristóteles (MONTGOMERY, 2000) e Ptolomeu (MACHADO, 2012). No caso de Darwin-Wallace, antes dos acontecimentos narrados, houve um contato entre ambos, registrado também em cartas de 1857, que decerto influenciou o trabalho dos dois e seus respectivos textos. Ademais, o que se fez depois em nome do darwinismo também demonstra a potência de interpretação do polo receptor, para o bem ou para o mal. Aqui talvez possamos lembrar das palavras de Michel Serres sobre o sujeito coletivo da ciência:

A partir do momento em que a ciência começa, o sujeito é imediatamente colectivo. [...] Nas ciências, apenas o nós conhece. O eu por vezes inventa, mas sabemos como a comunidade científica desconfia disso exatamente como a Igreja tem horror aos místicos. [...] Mas [...] o nós não funciona como um eu, longe disso (SERRES, 1996, p. 218-9).

Evidentemente, há questões colaterais ao problema da autoria, mas não menos importantes, como o plágio, as fraudes e as atribuições indevidas, bem como a própria formação científica, sobretudo no que diz respeito ao amadurecimento de uma escrita própria ${ }^{15}$. Não me aterei aqui a essas questões que, a meu ver, nada têm a ver com os moralismos que costumam frequentar essas discussões. Não me parece que enquadrar os indivíduos como bons ou maus, e criminalizá-los, resolva o problema. Como dizia Charles Buckowski (2013, p. 96-7): "A diferença entre um homem que faz o mal e aquele que não o faz é muito pequena. [...] Claro, haverá sempre um lobo fora da matilha. Mas este lobo se integrará cada vez mais à medida que a compreensão tomar o lugar do castigo." No meu entendimento, essas questões dizem respeito sobretudo à educação - formal e não formal -, que deveria formar humanos e não peças de engrenagem. Nos termos de Serres (1996, p. 244-7), deveria formar o "terceiro instruído", que "descreve uma revolução kepleriana" com uma elipse e seus dois focos, em vez do círculo perfeito com um centro irradiador de luz. Ou seja, uma instrução que reúne as duas culturas (ciências duras e humanidades), um sol e seu duplo. Mas isso é só uma digressão. O tema é deveras importante e exige aprofundamento, o que extrapola o objetivo deste artigo.

Para Roger Chartier, a inversão autoria-anonimato ocorrida entre a literatura e a ciência, proposta por Foucault, precisa ser revista urgentemente, pois não mais se aplica à luz das novas historiografias e tecnologias de leitura. A função-autor não diz respeito apenas à função discursiva, diz respeito também à materialidade do texto e à aliança entre o livro como objeto, o trabalho e o nome de seu autor. Além disso, na ciência do século XIV, por exemplo, mais do que autoridade, havia conhecimento anônimo e coletivo. Para demonstrar isso, ironicamente Chartier faz uma genealogia da autoria científica desde a invenção do copyright (autor como proprietário), passando pelas questões de propriedade moral ou econômica, até a relação entre autoridade política e autoria científica nos séculos XVI e XVII. Nesse ponto, ele retoma a crítica a Foucault, dizendo que não houve aí uma inversão autoria-anonimato, e sim uma ênfase na propriedade moral (ao contrário da literatura, que começava a mesclar os dois tipos de propriedade). Ainda sobre o século XIV, Chartier menciona um paradoxo:

Por muito tempo, a unidade de um livro não tinha nada a ver com uma ausência de função-autor. Tal unidade dependia da vontade do leitor que desejasse juntar diversos trabalhos em um único livro ou da atividade

15 Há várias tentativas de controlar esses problemas, como guias de boas práticas (de instituições e agências de fomento, como o da Fapesp), sites de retratação (por exemplo, o Retraction Watch, http://retractionwatch.com/) e comitês (por exemplo, o Cope, Comittee on Publication Ethics, que em junho de 2014 publicou um documento de discussão sobre o conceito de autoria). Cf. COPE, 2014; FAPESP, 2011. 
de um escriba que decidisse copiar e associar uma série de textos heterogêneos. [...] No entanto, [...] em certos trabalhos, essa definição tradicional e dominante do códex foi substituída por uma nova concepção do livro, oferecendo os trabalhos de apenas um autor ou apenas um de seus trabalhos. Isso foi um desenvolvimento de alguma maneira paradoxal num tempo em que escrever era frequentemente pensado como compilação ou reescrita [...]. A unidade estabelecida entre a integridade material do livro e a singularidade dos trabalhos que vêm do mesmo punho claramente mostra que alguns autores da época (que escreveram em vernáculo), desfrutaram da mesma 'dignidade codicológica' das antigas autoridades (CHARTIER, 2003, p. 26-7).

Ele ainda desdobra um pouco mais essas questões em outros livros, Os desafios da escrita (CHARTIER, 2002) e A aventura do livro: do leitor ao navegador (CHARTIER, 1998), conclamando-nos a rever o conceito de autoria jurídica, estética, administrativa e biblioteconomicamente, tendo em vista essa nova materialidade dos textos. O conceito de autoria foi construído no bojo de uma "cultura escrita cujos objetos eram totalmente diferentes dos textos eletrônicos", diz ele (CHARTIER, 2002, p. 117).

Apesar dessa natureza mutável do conceito, radicalizada com as práticas derivadas das novas formas de comunicação em rede, as normas que vigoram ainda se baseiam num conceito de autoria individual. Esse descompasso é tratado no livro Autoria em rede, de Beatriz Martins (2014), com uma série de estudos empíricos. Dentre as questões que se destacam, a avaliação me interessa em particular porque essas novas formas interativas de criação produzem uma autoria distribuída e, portanto, demandam novos sistemas de avaliação sobretudo diante do grande número de intervenções possíveis em grandes projetos. Segundo ela: "O modelo distribuído de legitimação da produção textual acompanha as novas formas autorais interativas, e pode representar, ao mesmo tempo, a escolha conceitual por um sistema de validação feito do mesmo modo interativo, e também uma decisão pela eficácia” (MARTINS, 2004, p. 111). Vale anotar que um dos estudos empíricos que ela apresenta é sobre a Wikipedia, uma empreitada interativa de grande porte. Na mesma linha, é importante mencionar o projeto AIME, encabeçado por Bruno Latour, mas com centenas de colaboradores nos quatro cantos do planeta, que são considerados coautores. Trata-se de um projeto de pesquisa colaborativo e interdisciplinar em andamento há mais de duas décadas sobre os modos de existência, cujos resultados foram recentemente publicados em livro ${ }^{16}$. Em ambos os casos, a ideia de "comum", presente, por exemplo, no Wikimedia Commons, banco de imagens de domínio público ou com licença Creative Commons ${ }^{17}$, está implícita por conta do modelo colaborativo de produção. Trata-se da marca desse descompasso entre os novos conceitos de autoria e as práticas normativas vigentes.

Em seu texto O autor coletivo, Peter Galison (2003) faz uma análise interessante do caráter colaborativo em grandes empreitadas científicas com mais de mil participantes, como os grandes projetos da área de física de partículas das duas últimas décadas do século XX. Para além de questões de ordem prática, como avaliar em casos de contratação e promoção ou como detectar erros quando nem todos os participantes são capazes de julgar a publicação final, sua questão gira em torno do que significa, numa colaboração, saber algo sobre o mundo e como isso se relaciona com o que as pessoas de fora são convidadas a aceitar.

Para dar conta disso, ele volta a Kant, resgatando uma noção de autor transcendental, para desmobilizá -la de um "eu" individual para um "nós" coletivo. Na sequência, ele fala em pseudos-eus que caracterizariam colaborações típicas dos anos 1960, nas quais, independentemente das composições, os vários subgrupos se reportariam a um único centro, representado por um único líder, o grupo de fulano.

Com o tempo, essa unidade vai se desintegrando com a multiplicação de centros, as mudanças tecnológicas e o aumento da colaboração entre grupos, instituições e nações. Nenhum grupo pode comandar tudo, e a autoria, nessa altura, já está longe de ser igualitária, ou seja, "colaboração não significa compartilhar igualdade em autoridade; [...] indivíduos, grupos ou mesmo nações não podem mais se juntar a uma cola-

16 Ainda não pude estudá-lo sistematicamente, mas fica aqui o registro. Cf. http://www.modesofexistence.org/ e http://brunolatour.fr/.

17 Tipo de licença flexível que facilita o compartilhamento, a recombinação e a livre circulação de conteúdo digital, propondo que alguns direitos sejam reservados, em vez de todos (copyright) ou nenhum (domínio público). Para obter mais informações, cf. http://creativecommons.org/. 
boração em uma posição subordinada fixa" (GALISON, 2003, p. 330). Essa autoria descentralizada reflete novas condições de produção que exigem protocolos de autoria para garantir o crédito e a responsabilidade. Há casos em que "algumas colaborações [...] desencorajam a retirada de nomes da lista de autores [...]. Outros proíbem especificamente que um indivíduo ou grupo assine uma publicação com seus próprios nomes." (GALISON, 2003, p. 344). Enfim, esses protocolos servem para "que o 'nós' da colaboração possa produzir ciência defensável e autorizada" (GALISON, 2003, p. 345).

Mas as coisas não param por aí. Hoje vivemos tempos de big data e agentes móveis (programas que se autopropagam, capazes de saltar de um computador para outro, dissolvendo relações hierárquicas de acesso e controle). Não é mais possível fazer ciência sem lidar com essa nova realidade, e isso também afeta a autoria. Não se trata mais de "eu" ou "pseudo-eu". "Esse novo sujeito é coordenado, mas não comandado, a partir de um ponto, funcionando mais como uma colmeia do que uma hierarquia." (GALISON, 2003, p. 348). Para finalizar, Galison ainda diz que não se trata de consenso (Kuhn) nem murmúrio (Foucault), o porta-voz fala o que o grupo pôde reunir, e isso é ao mesmo tempo uma construção do grupo e do argumento apresentado. É uma voz coletiva.

Vale lembrar que Knorr-Cetina (1999, p. 389-90), em seu artigo “A comunicação na ciência”, já havia identificado esse mecanismo de "eliminação do físico individual enquanto autor, através de publicações estritamente colectivas em ordem alfabética". A esse mecanismo, ela ainda agrega mais um que corta o laço entre autor e produto: a transformação do indivíduo em representante do grupo. Ou seja, ao apresentar um trabalho num congresso, por exemplo, não se trata de um autor divulgando o seu artigo, e sim um porta-voz do grupo, que às vezes nem participou da escrita do texto comunicado.

No texto "Direitos ou reconhecimentos? Mudando as estruturas da autoria científica", Mario Biagioli (2003) vai na mesma direção de Galison, apontando para uma mudança no conceito de autoria científica em tempos de big science com seus novos modos de produção, mas vai além a partir de uma análise comparativa da autoria na biomedicina e em grandes projetos da física.

Ao analisar alguns periódicos na biomedicina, Biagioli percebe que há controvérsias sobre a categoria "autor", que pode chegar a incluir todos os colaboradores, desde que cada um deles declare a parte que fez, e também "fiadores" (guarantors), que não são os primeiros autores nem os mais experientes. Trata-se daqueles atores que serão responsabilizados pelo todo em caso de auditoria ou fraude. Nos grandes laboratórios de física, ao contrário, há protocolos detalhados de autoria e, em caso de má conduta, as questões são resolvidas internamente, tendo em vista que as colaborações são em grande número e com várias instituições e quase não há especialistas fora da comunidade, o que significa que praticamente não é possível sobreviver fora dela. Isso, de alguma maneira, regula as práticas e fortalece a noção de responsabilidade.

Apesar das diferenças, Biagioli afirma que, em ambos os casos, a autoria está perdendo seu papel de "receptáculo de crédito e responsabilidade [...], muito embora os nomes dos cientistas ainda sejam cruciais para a economia da ciência” (GALISON, 2003, p. 274). Mas a lógica dessa economia está mudando de um essencialismo para um operacionalismo, redistribuindo as funções de autoria por equipes, corporações ou procedimentos. Ou seja, a autoria coletiva não é um problema, mas algo autorizado.

Sendo assim, pode-se dizer que a autoria científica é um "vestígio histórico" (GALISON, 2003, p, 274) que nada tem a ver com direitos, mas sim com reconhecimento. A responsabilidade científica tampouco é uma questão legal, trata-se de um "conjunto de relações entre colegas" (GALISON, 2003, p. 274). Com isso, uma possibilidade de saída do impasse é de fato assumir um conceito de autoria científica diferente para cada disciplina.

Antes de finalizar esta seção, é preciso falar também dos autômatos, algoritmos e programas capazes de produzir, por exemplo, um texto. Por mais estranho que isso possa parecer, tendo em vista a noção moderna de autor como sujeito, e portanto humano, ninguém negaria, por exemplo, a função instrumental dos computadores, que, além de rodarem os editores de textos e outros programas que auxiliam a escrita e a pesquisa, servem como memória auxiliar, um tipo de "potente prótese de memória dotada de um extraordinário 
poder de cálculo, muito superior ao homem" (MARTINS, 2014, p. 79). Trata-se de híbridos que cada vez mais habitarão o nosso mundo. Mas serão eles autores ou coautores?

Os softwares "What would I say?", AARON ${ }^{18}$ e SCIgen ${ }^{19}$ são exemplos interessantes para pensar essa questão e dizem respeito, respectivamente, à autoria na poesia, nas artes plásticas e na ciência da computação. Em poucas palavras, o primeiro participa de uma "literatura do acaso", produzindo frases aleatórias que são tratadas e finalizadas pelo poeta, que vira aqui um meta-autor. $\mathrm{O}$ mesmo acontece com o segundo, mas de um modo bem diferente, pois o programa é alimentado com as instruções necessárias para compor uma pintura. O produto final é feito pelo programa, mas ele não faria isso sem ter sido alimentado antes pelo pintor. No meio científico também já há programas que escrevem artigos, como o SCIgen, que produz artigos a partir da combinação de palavras aleatórias. Ele foi criado no MIT para desmascarar periódicos na área da ciência da computação que aceitam publicar artigos sem a devida revisão por pares. No entanto, trata-se de um software livre que qualquer um pode baixar na internet, ou seja, ele pode e tem sido usado na produção de artigos completamente sem sentido para além do experimento do MIT. Isso significa que, se a revisão por pares não for bem-feita, o artigo pode ser aceito para publicação. Evidentemente, alguns mecanismos de detecção desse tipo de fraude ou similares já foram desenvolvidos, mas não é difícil imaginar um cenário em que esse tipo de prática se dissemine ${ }^{20}$.

Vale lembrar também o caso do selfie da macaca (cf. Anexo 3). O ano de 2014 testemunhou uma discussão inédita que resultou no reconhecimento legal de um animal não humano como autor de uma fotografia (KANG, 2014). Resumidamente a história é a seguinte: o fotógrafo britânico David Slater, reconhecido especialista em vida selvagem, estava visitando um parque na Indonésia, preparando-se para fotografar os animais da espécie macaca nigra, quando um deles pegou uma de suas câmeras e, junto com outros, começou a sacar várias fotos, sendo que uma delas, que ficou conhecida como "o selfie da macaca", tornou-se um sucesso na internet depois de já ter sido publicada pelo fotógrafo. A Wikimedia Commons assume que a foto foi tirada pela macaca, portanto é de domínio público, então não há créditos devidos. Slater alega que possui os direitos autorais da foto, já que a máquina era dele e o ambiente foi ele que preparou, colocando a máquina sobre o tripé e ajustando o foco. Ele só não tinha apertado o botão. Em termos legais, a situação no momento é a seguinte: nos Estados Unidos, a Wikimedia ganhou, porque se entendeu que a "autora" da foto era a macaca já que foi ela que apertou o botão, então não havia créditos devidos, tendo em vista que a categoria de autoria só se aplica a humanos. A foto foi considerada de domínio público. No Reino Unido, o processo ainda está em andamento, mas é possível que o fato de Slater não ter apertado o botão seja considerado secundário diante do que pode vir a ser considerado sua "criação intelectual". Ou seja, ele preparou o equipamento e o ambiente, tinha um projeto fotográfico, e as fotos foram sacadas, muito embora de maneira inusitada. História parecida com a dos programas mencionados acima.

Aparentemente, nossos colaboradores estão se diversificando e - ainda que a afirmação a seguir demande mais pesquisa e seja absolutamente provisória - não me parece que seja só no sentido instrumental, talvez seja esta a nova face da autoria científica. Um encontro entre humanos e não humanos que pode ser deveras produtivo, não exatamente o "anonimato do murmúrio" de Foucault, já que os mecanismos de controle e responsabilização estão cada vez mais sofisticados, mas algo parecido, tendo em vista que aos grandes coletivos científicos se agregam artefatos e animais não humanos que de alguma maneira são partícipes da empreitada.

18 Para saber mais sobre ambos, cf. https://autoriaemrede.wordpress.com/2014/01/16/aaron-um-software-artista/. Especificamente sobre o "What would I say?", cf. http://oglobo.globo.com/blogs/prosa/posts/2013/12/14/literatura-doacaso-as-experiencias-com-bot-what-would-say-518117.asp; e sobre o AARON, cf. http://www.viewingspace.com/genetics culture/pages genetics culture/gc w05/cohen h.htm.

19 Cf. Artigos nonsense. Pesquisa Fapesp, 219, 9. Acesso em 11 de janeiro de 2015. Disponível em: http://revistapesquisa.fapesp. br/2014/05/15/artigos-nonsense/. O site do software no MIT é o seguinte: http://pdos.csail.mit.edu/scigen/.

20 Além do já citado Retraction Watch, que é um blog do tipo observatório de fraudes, que tem como principal característica denunciar fraudes ou suspeitas de fraudes e divulgar retratações, podemos mencionar, por exemplo, o Turnitin, software de detecção de plágio (http://turnitin.com/), que tem a integridade da escrita acadêmico-científica como principal meta. 


\section{Considerações finais}

É chegada a hora de finalizar, apesar de muitos problemas terem sido expostos e nem todos devidamente explorados. Fica aqui a promessa para trabalhos futuros. De qualquer modo, apesar de muitos pontos de interrogação, ninguém negaria hoje que a ciência é uma empreitada coletiva que implica uma literatura científica cada vez mais colaborativa. Pensar o problema da autoria, portanto, torna-se fundamental para reconhecer, responsabilizar e dar crédito, sobretudo em tempos de produtivismo avaliado com base em bibliometria. Ou seja, à pergunta "Que importa quem fala?", feita por Foucault (1969) num contexto em que ele responderia com o "anonimato do murmúrio" (FOUCAULT, 1969, p. 70), que talvez possamos associar ao "pseudo-eu" de Galison (2003, p. 328), caberia hoje a resposta: importa para avaliar a produção científica.

Podemos - e devemos - questionar essa realidade de práticas avaliativas exclusivamente quantitativas que produz criaturas monstruosas, como hiperprodução, salami science etc., mas isso não pode ser feito sem pensar o problema da autoria, que ganhou novos matizes. Nos termos de Galison (2003), saímos da situação de um autor individual (eu), passamos pelo autor coletivo, que ainda centralizava o conhecimento (pseudo-eu) e agora estamos vivendo uma variação desse autor coletivo, um tipo de "eu colmeia", que se caracteriza por desunidade e mobilidade. Como vimos em Foucault (1969) e Latour (1987), a distinção entre o "autor de carne e osso" e o "autor no papel" passa pelo enquadramento e pela encenação, que são algumas das estratégias de escrita para capturar o leitor-alvo. Para Knorr-Cetina (1999), como em Galison (2003), a autoria individual desaparece em alguns contextos e surgem os porta-vozes, ator científico já mencionado por Latour (1987). Nos termos de Mendonça (2014), a síndrome da ostensiva mercantilização acadêmica implica inversão de valores, inclusive uma série de práticas autorais que, na melhor das hipóteses, refletem as estratégias de escrita de Latour que vimos na primeira seção deste artigo. Para tornar a questão ainda mais complexa, Chartier (2002) nos lembra que outra materialidade textual, como a que vivemos atualmente, demanda outro conceito de autoria, que, nos termos de Martins (2014), não pode fugir da noção de autoria em rede.

Como pensar em avaliação com base na literatura científica, considerando a emergência desse novo tipo de autor e dessa nova cultura material, que implicam novas práticas interativas? Como fazer isso diante, por exemplo, da imagem de ciência de Latour, na qual os atores se multiplicaram e diversificaram? Ao que tudo indica, só nos resta atribuir esse valor de autoria aos porta-vozes, produzindo uma nova definição de autoria científica.

Diante disso, talvez tenha chegado a hora de, junto com Barthes (2004), decretar a morte do autor junto com o projeto de modernidade e a sua distinção obsoleta entre ciência e política, ou natureza e cultura - e restituir o lugar do leitor, da recepção e da distribuição do conhecimento. Esta pode vir a ser a última pá de cal na ideia de genialidade associada à autoria, bem como pode vir a ser um movimento necessário para desacelerar a ciência e dar conta da sua maior aproximação com a sociedade.

Mas será isso suficiente? Talvez o mais importante, como nos sugerem alguns casos aqui relatados, seja parar para pensar, deixar de lado este "ser ou não ser" autor e assumir definitivamente um "estar de passagem" para outra coisa. Será que o modelo da big fast science, com suas aparelhagens institucionais, sua (re)produção desenfreada, seu "epistemicídio" decorrente das atuais práticas de avaliação das revistas científicas, é viável? Será que não está na hora de começar a elaborar políticas de "ciência menor", incentivando a proliferação de pequenos grupos e métricas alternativas, e a criação de novas possibilidades de atuação? Minha modesta opinião é que a hora é esta. 


\section{Referências bibliográficas}

ALLEN, Liz et al. Publishing: Credit where credit is due. Nature, 2014. Vol. 508, nº. 7496, p. 312-3. Disponível em: $<$ http://www.nature.com/news/publishing-credit-where-credit-is-due-1.15033>. Acesso em: janeiro de 2015.

ARNS, Martijn. Open access is tiring out peer reviewers. Nature, 2014. Vol. 515, p. 467. Disponível em: http://www. nature.com/news/open-access-is-tiring-out-peer-reviewers-1.16403. Acesso em: janeiro de 2015.

BARTHES, Roland. A morte do autor. In: O rumor da língua. Tradução de Mario Laranjeira. SP: Martins Fontes, 2004 [1968].

BIAGIOLI, Mario. Rights or rewards? Changing framework of scientific authorship. In: BIAGIOLI, Mario; GALISON, Peter (Eds.). Scientific authorship: credit and intellectual property in science. NY: Routledge, 2003.

BROWNE, Janet. A origem das espécies de Darwin: uma biografia. Tradução de Maria Luiza Borges. RJ: Jorge Zahar Ed., 2007.

BUCKOWSKI, Charles. Pedaços de um caderno manchado de vinho. Tradução de Pedro Gonzaga. Porto Alegre: L\&PM, 2013.

CAMARGO JR., Kenneth; COELI, Claudia. Múltipla autoria: crescimento ou bolha inflacionária? Rev Saúde Pública, vol. 46, n. 5, p. 894-900, 2012.

CASTIEL, Luis David; SANZ-VALERO, Javier; VASCONCELOS-SILVA, Paulo Roberto. Das loucuras da razão ao sexo dos anjos: biopolítica, hiperprevenção, produtividade científica. RJ: Editora Fiocruz, 2011.

CHARTIER, Roger. Foucault's chiasmus: authorship between science and literature in the seventeenth and eighteenth centuries. In: BIAGIOLI, Mario; GALISON, Peter (Eds.). Scientific authorship: credit and intellectual property in science. NY: Routledge, 2003.

Os desafios da escrita. Tradução de Fulvia Moretto. SP: Editora Unesp, 2002.

. A aventura do livro: do leitor ao navegador. Conversações com Jean Lebrun. Tradução de Reginaldo Moraes. SP: Editora Unesp, 1998.

COLLINS, Harry. A comunidade científica em tempos de disputa. In: GIL, Fernando (Org.). A ciência tal qual se faz. Tradução de Paulo Tunhas. Lisboa: Edições João Sá da Costa, 1999.

COPE. What constitutes authorship? Cope discussion document, junho 2014. Disponível em: publicationethics.org. Acesso em: janeiro 2015.

Darwin Correspondence Project. Disponível em: <http://www.darwinproject.ac.uk/>. Acesso em: janeiro de 2015.

DASCAL, Marcelo. A polêmica na ciência. In: GIL, Fernando (Coord.). A ciência tal qual se faz. Lisboa: Edições João Sá da Costa, 1999.

DOMINGUES, H. M. B.; SÁ, M. R.; GLICK, T. (Orgs.). A recepção do darwinismo no Brasil. RJ: Editora Fiocruz, 2003. FAPESP. Código de boas práticas científicas. São Paulo, 2011.

FIORAVANTI, Carlos. Os primeiros journals. Revista Fapesp, 227, p. 74-5, janeiro de 2015.

FOUCAULT, Michel. O que é um autor? Tradução de António Cascais e Eduardo Cordeiro. Lisboa: Nova Veja, 2006 [1969]. . A ordem do discurso. Tradução de Laura Sampaio. SP: Edições Loyola, 1999 [1970].

A escrita de si. In: . Ditos e escritos V: Ética, sexualidade, política. Rio de Janeiro: Forense Universitária, 2012 [1983].

FRISCHE, Sebastian. It is time for full disclosure of author contributions. Nature. 2012, vol. 489, nº. 7417, p. 475. Disponível em: <http://www.nature.com/news/it-is-time-for-full-disclosure-of-author-contributions-1.11475\#a1 >.

FULLER, Steve. The philosophy of science and technology studies. NY-Londres: Routledge, 2006.

GALISON, Peter. The collective author. In: BIAGIOLI, Mario; GALISON, Peter (Eds.). Scientific authorship: credit and intellectual property in science. NY: Routledge, 2003.

GOMES, Marina; CUNHA, Rodrigo; PALLONE, Simone (Eds.). Dossiê “Cultura de indicadores de CTI”. Com Ciência, 166, 10 de março de 2015. 
KANG, Jay. Wikipedia defends the monkey selfie. The New Yorker, 8 de agosto de 2014. Disponível em: <http://www. newyorker.com/news/daily-comment/monkey-see-monkey-click.

KNORR-CETINA, Karin. A comunicação na ciência. In: GIL, Fernando (Org.). A ciência tal qual se faz. Tradução de Paulo Tunhas. Lisboa: Edições João Sá da Costa, 1999.

LATOUR, Bruno. Literatura. In: . Ciência em ação: como seguir cientistas e engenheiros sociedade afora. Tradução de Ivone Benedetti. SP: Editora Unesp. 2011 [1987].

MARQUES, Fabricio. O índice h. Revista Fapesp, 207, p. 35-39, 2013. Disponível em: < http://revistapesquisa.fapesp. br/2013/05/14/os-limites-do-indice-h/>.

MARTINS, Beatriz Cintra. Autoria em rede: os novos processos autorais através das redes eletrônicas. RJ: MauadX, 2014.

MENDONÇA, André Luis de Oliveira. Dos valores de medida aos valores como medida: uma avaliação axiológica da avaliação acadêmica. Ensaios Filosóficos, volume X, p. 111-133, dezembro 2014.

MACHADO, Cristina de Amorim. O papel da tradução na transmissão da ciência: o caso do Tetrabiblos de Ptolomeu. RJ: Editora MauadX, 2012.

MONTGOMERY, Scott L. Science in translation: movements of knowledge through cultures and time. Chicago: University of Chicago Press, 2000.

PAPAVERO, Nelson; SANTOS, Christian Fausto Moraes dos. Evolucionismo darwinista? Contribuições de Alfred Russel Wallace à teoria da evolução. Revista Brasileira de História, São Paulo, v. 34, n. 67, p. 159-180, 2014.

REIS, Verusca; VIDEIRA, Antonio. John Ziman e a ciência pós-acadêmica: consensibilidade, consensualidade e confiabilidade. Scientiae Studia, São Paulo, v. 11 (3), p. 583-611, 2013.

SCHOPENHAUER, Arthur. A arte de escrever. Tradução de Pedro Süssekind. Porto Alegre: L\&PM, 2013.

SERRES, Michel. Diálogo sobre a ciência, a cultura e o tempo: conversas com Bruno Latour. Tradução de Serafim Ferreira e João Paz. Lisboa: Instituto Piaget, 1996.

STENGERS, Isabelle. Une autre science est possible! Manifeste pour un ralentissement des sciences. Paris: Éditions La Découverte, 2013.

THELVALL, Mike. A brief history of altmetrics. Research Trends, 37, jun 2014. Disponível em: <http://www.researchtrends.com/issue-37-june-2014/a-brief-history-of-altmetrics/>.

VAN WYHE, John. The complete work of Charles Darwin online, 2002. Disponível em: <http://darwin-online.org.uk/>. VAN WYHE, John; ROOKMAAKER, Kees. A new theory to explain the receipt of Wallaces's Ternate essay by Darwin in 1858. Biological Journal of the Linnean Society, 105, p. 249- 252, 2012.

ZIMAN, John. A ciência na sociedade moderna. In: GIL, Fernando (Coord.). A ciência tal qual se faz. Lisboa: Edições João Sá da Costa, 1999. 


\section{Aneko 1}

Projeto de pesquisa para submissão à Chamada Univesal MCTI/CNPq No 014/2014

1) Identificação da proposta

Título: Ciência, tecnologia e inovação à luz dos Science Studies: (re)construindo relações entre tecnociência e sociedade

Local de realização do projeto: DFE / UEM

Proponente: Profa. Dra. Cristina de Amorim Machado (professora adjunta - DFE/UEM)

CV: http://buscatextual.cnpq.br/buscatextual/visualizacv.do? metodo=apresentar\&i$\mathrm{d}=\mathrm{K} 4716862 \mathrm{E} 8$

\section{Resumo:}

Este projeto de pesquisa é a continuação de um trabalho que está sendo realizado há quase dois anos e que já conta com um auxílio do CNPq (Processo 408437/2013-8) oriundo da chamada MCTI/CNPq/MEC/CAPES no. 43/2013 (Ciências Humanas, Sociais e Sociais Aplicadas). Agora precisamos montar nossa biblioteca e seguir trabalhando, a fim de aprofundar a pesquisa em andamento. Conforme dito no projeto anterior, partimos do princípio de que o discurso que associa ciência, tecnologia e inovação tornou-se hegemônico nos últimos anos. Assim, as três instâncias parecem estar naturalmente ligadas e, portanto, desproblematizadas. Contudo, problematizá-las é tarefa de quem faz, pensa e organiza as ciências, e este projeto pretende dar uma contribuição nesse sentido tomando os Science Studies como base teórico-metodológica. Dentre outras metas, os Science Studies pretendem aproximar ciência e sociedade enfatizando a ciência tal qual se faz. Distinguem-se, portanto, da Filosofia da Ciência que nasceu em Viena na década de 1920, cujo foco é a produção teórica das ciências. É nesse sentido que entendemos as discussões não só dos membros do Círculo de Viena, como também as de Popper, Lakatos, Kuhn e Feyerabend, ainda que cada um deles tenha apontado para novos horizontes de compreensão das ciências. Por outro lado, para adeptos dos Science Studies, como Hacking, Latour e Galison, só para citar alguns, o foco tem sido a prática científica, ou seja, as ciências são tratadas como práticas locais condicionadas social, material e culturalmente, mas que também são condicionantes do contexto social em que estão inseridas. No entanto, parece haver uma assimetria nessa relação entre ciência e sociedade, pendendo mais para a primeira, o que conduziria os Science Studies a uma "anemia política". Diante dessa hipótese, precisamos, por um lado, pesquisar mais em que medida isso pode ser afirmado com base no que vem sendo publicado pelos autores dos Science Studies; e por outro, avançar uma discussão sobre como fazer Science Studies no Brasil, considerando o discurso predominante da inovação, a sua íntima relação com as questões da tecnociência e o seu diálogo com a sociedade.

Palavras-chave: Tecnociência e sociedade. Science Studies. Ciência, tecnologia e inovação. 
On the Tendency of Species to form Varieties; and on the Perpetuation of Varieties and Species by Natural Means of Selection. By Charues Darwin, Esq., F.R.S., F.L.S., \& F.G.S., and Alfred Wamiace, Esq. Communicated by Sir Charles Lreul, F.R.S., F.L.S., and J. D. Hooker, Esq., M.D., V.P.R.S., F.L.S., \&c.

\section{[Read July 1st, 1858.]}

London, June 30th, 1858.

Mr Dear Srr,-The accompanying papers, which we have the honour of communicating to the Linnean Society, and which all relate to the same subject, viz. the Laws which affect the Production of Varieties, Races, and Species, contain the results of the investigations of two indefatigable naturalists, Mr.Charles Darwin and Mr. Alfred Wallace.

These gentlemen having, independently and unknown to one another, conceived the same very ingenious theory to account for the appearance and perpetuation of varieties and of specific forms on our planet, may both fairly claim the merit of being original thinkers in this important line of inquiry; but neither of them having published his views, though Mr. Darwin has for many years past been repeatedly urged by us to do so, and both authors having now unreservedly placed their papers in our hands, we think it would best promote the interests of science that a selection from them should be laid before the Linnean Society.

Taken in the order of their dates, they consist of :-

1. Extracts from a MS. work on Species*, by Mr. Darwin, which was sketched in 1839, and copied in 1844, when the copy was read by Dr. Hooker, and its contents afterwards communieated to Sir Charles Lyell. The first Part is devoted to "The Variation of Organic Beings under Domestication and in their Natural State;" and the second chapter of that Part, from which we propose to read to the Society the extracts referred to, is headed, "On the Variation of Organic Beings in a state of Nature; on the Natural Means of Selection; on the Comparison of Domestic Races and true Species."

2. An abstract of a private letter addressed to Professor Asa Gray, of Boston, U.S., in October 1857, by Mr. Darwin, in which

* This MS. work was never intended for publication, and therefore was not written with care--C. D. 1858. 


\section{Anexo 3}

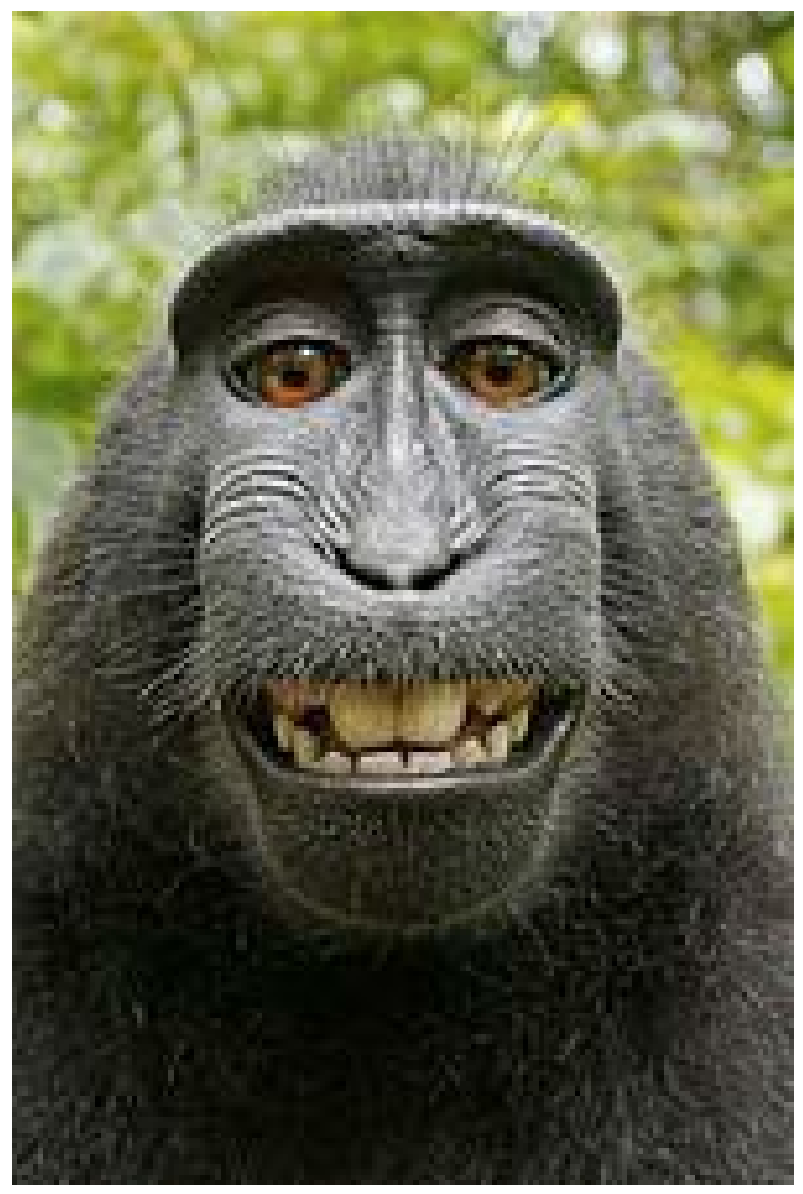

O selfie da macaca.

Fonte: Wikimedia Commons. 